\title{
Diversity or Redundancy in Leaf Physiological and Anatomical Parameters in a Species Diverse, Bottomland Hardwood Forest?
}

\author{
Zeima Kassahun, Justin N. Yow and Heidi J. Renninger *(D) \\ Department of Forestry, Mississippi State University, Mississippi State, MS 39762, USA; \\ zeimakassahun@gmail.com (Z.K.); justin.yow@unco.edu (J.N.Y.) \\ * Correspondence: hr427@msstate.edu
}

Received: 26 March 2020; Accepted: 1 May 2020; Published: 6 May 2020

\begin{abstract}
Research Highlights: Bottomland hardwood forests exhibit seasonal flooding, are species diverse, and provide numerous ecosystem services including floodwater storage, wildlife habitat and nutrient mitigation. However, data are needed to adequately predict the potential of individual species to achieve these services. Background and Objectives: In bottomland hardwood forests, increasing tree species richness may increase functional diversity unless species exhibit an overlap in physiological functioning. Therefore, the objectives of this study were to (1) compare physiological and anatomical leaf parameters across species, (2) determine if leaf anatomical and nutrient properties were correlated with physiological functioning, (3) determine intra-species variability in leaf stomatal properties and determine how whole crown metrics compare with leaves measured for gas exchange and (4) measure soil nitrogen for evidence of denitrification during inundation periods. Materials and Methods: We measured gas exchange, leaf nutrients and anatomical properties in eight bottomland hardwood species including Carya ovata, Fraxinus pennsylvanica, Quercus michauxii, Quercus nigra, Quercus pagoda, Quercus phellos, Ulmus alata and Ulmus americana. Additionally, we quantified soil ammonium and nitrate content during winter inundated conditions to compare with non-inundation periods. Results: We found that leaf-level water use parameters displayed greater variability and diversity across species than photosynthesis and leaf nitrogen parameters, but green ash and shagbark hickory exhibited generally high leaf $\mathrm{N}$ concentrations and similar physiological functioning. Elms and oaks displayed larger variability in leaf physiological functioning. Stomatal density was significantly correlated with photosynthetic capacity and tree-level water use and exhibited high intra-species variability. Conclusions: This bottomland hardwood forest contains more diversity in terms of water use strategies compared with nitrogen uptake, suggesting that differences in species composition will affect the hydrology of the system. Green ash and shagbark hickory exhibit higher leaf nitrogen concentrations and potential for nutrient mitigation. Finally, leaf anatomical parameters show some promise in terms of correlating with leaf physiological parameters across species.
\end{abstract}

Keywords: $A / C_{i}$ curves; floodplain forests; leaf structure function; Quercus; resource use efficiency; stomata

\section{Introduction}

Bottomland hardwood forests are an important, but understudied, ecosystem relative to other temperate forests. Once a prevalent and continuous system, a majority of bottomland hardwood forests in the United States (US) have been lost or fragmented due to anthropogenic activities [1]. The current extent of bottomland hardwood forests is most prevalent on the Gulf and Atlantic Coastal Plains due to the geomorphology of these regions [2]. Bottomland hardwood forests are made up of over 70 different tree species, co-occurring to form numerous plant community types [3]. 
The development of bottomland hardwood plant communities is strongly influenced by relative flooding depth and duration, with the possible number of suitable community types increasing from hydric to mesic sites [3]. The high presence of soil organic matter, low oxygen concentrations, and low redox potential associated with bottomland hardwood soils can create the appropriate conditions for nitrogen transformations [4,5]. Thus, the restoration of bottomland hardwood forests can be an effective tool for removing excess nitrogen from systems [5], which will reduce the eutrophication of nearby waterways.

Bottomland hardwood forests offer several important ecosystem services including nitrogen removal, the buffering of floodwaters, carbon sequestration, and habitat provision, and recent efforts have been undertaken to afforest abandoned farmland [6] through private and government-sponsored programs. However, variability in bottomland hardwood site and species characteristics, coupled with varying management objectives and changing climate conditions, can severely affect restoration success [7]. Therefore, knowledge of species-specific physiological attributes of common bottomland hardwood species can inform restoration efforts to match species with site conditions and better predict ecosystem services based on species composition. For example, species with high water use and photosynthetic capacity but low water use efficiency may be more successful in more hydric environments, while species that exhibit higher water use efficiency may be more successful on ridges or terraces. Additionally, species with high levels of leaf nitrogen may perform better at removing excess nitrogen from the system and provide water quality services, while species with greater photosynthetic nitrogen use efficiency may perform better in low nitrogen environments.

Species-specific functional parameters including photosynthetic capacity, water use efficiency, leaf nitrogen and photosynthetic nitrogen use efficiency determine the productivity, water use, nutrient dynamics, and functional characteristics of forest ecosystems and are used in the larger scale modeling of these ecosystems. However, a large diversity in species composition may indicate large functional diversity as well, which could increase the complexity of modeling efforts. In addition, it is unclear whether species within a genus will be more similar compared with differences across genera. Species composition within sites has been shown to be a larger contributor of variation in leaf parameters than site differences [8-10]. The species diversity of bottomland hardwood systems has the potential to increase the exploitation of canopy [11] and belowground space to utilize resources more efficiently and increase overall site productivity [12,13]. However, increases in species richness do not necessarily increase the functional diversity of the system, and if species overlap in their physiological functioning, forests with high species diversity may not necessarily exhibit functional diversity and the accompanying ecological benefits $[12,14]$. In addition, species may not aggregate in physiological functioning based on taxonomic categories of genus or family [8]. Determining the extent of functional diversity within an ecosystem can strengthen the modeling accuracy of stand-level productivity, water use, structure, and composition [15,16]. Quantifying functional diversity across species can also inform restoration efforts to achieve an optimum species composition to accomplish the desired management goals of high productivity, nitrogen remediation or other ecosystem services.

In addition to the variability that can result from high species richness across species, high variability in physiological functioning within tree crowns can also complicate modeling efforts. Within individual tree crowns, variability in light levels, leaf temperature and wind speed leads to vertical gradients in leaf structural and physiological parameters [17]. However, determining the variability within crowns in terms of leaf functioning is difficult and time consuming. While leaf mass per unit area (LMA) has traditionally been used as a leaf anatomical parameter to correlate with functional parameters, leaf stomatal properties are another option to infer physiological functioning based on their role in leaf gas exchange, photosynthetic productivity and transpiration rates as well as being relatively simple properties to measure [18]. However, it remains unclear to what extent stomatal properties vary in leaves across tree crowns, if species exhibit differing plasticity in stomatal properties, and whether stomatal properties correlate with tree-level physiological parameters-specifically, water use. Determining intra-species variability in stomatal properties 
as well as the usefulness of stomatal properties in predicting tree functioning can aid in tree and stand-level modeling efforts $[19,20]$.

The objectives of this study were as follows: (1) to determine if significant differences exist in leaf physiological, biochemical and anatomical properties across eight species and four genera/families growing in a southeastern US bottomland hardwood forest and if species are more similar within genera than across genera. This will allow for the determination of inter-species variability across various physiological parameters to determine the degree of functional diversity occurring at this site; (2) to determine which leaf anatomical (LMA and stomatal properties) and nutrient/biochemical parameters are most highly correlated with physiological parameters across measured individuals, specifically Rubisco-limited carboxylation rate $\left(\mathrm{V}_{\mathrm{Cmax}}\right)$ and whole tree water use parameters, and determine correlations between resource use efficiency parameters, specifically photosynthetic nitrogen use efficiency (PNUE) and water use efficiency. If correlations are found and divergent species exhibit similar trends, it can allow for the refinement of models predicting stand-level carbon assimilation and water use from endogenous leaf factors in this forest type; (3) to determine the intra-species variability in leaf stomatal properties and compare variability across species. In addition to providing comparisons within and across species, this information can be important in determining how much variation occurs in stomatal anatomy, and in turn, potential leaf physiology. Therefore, leaves measured for physiological gas exchange will be compared with larger canopy variation in stomatal properties to determine whether measured leaf physiology (from accessible branches) was similar to, or different from, potential crown-level physiological metrics; (4) to determine if evidence exists for denitrification during the winter period of soil saturation in this forest. For bottomland hardwood forests, soil inundation can lead to denitrification, which can either be useful for nitrogen mitigation in situations of excess nitrogen or potentially cause decreased nitrogen availability in the ecosystem if nitrogen is limited. Low nitrogen availability could limit leaf nitrogen content and associated physiological traits across species depending on their nitrogen uptake capacity. The study includes four Quercus (Fagaceae) species; Quercus pagoda Raf. (section- Lobatae), Quercus nigra L. (section- Lobatae), Quercus phellos L. (section- Lobatae) and Quercus michauxii Nutt. (section: Quercus), two Ulmus (Ulmaceace) species; Ulmus americana L. and Ulmus alata Michx., one Carya (Juglandaceae) species; Carya ovata (Mill) K. Koch and one Fraxinus (Oleaceae) species; Fraxinus pennsylvanica Marshall. Overall, these data will help us to determine water and nitrogen use strategies that maximize carbon assimilation within species and the variability occurring among and within species in this bottomland forest system. Identifying species-specific and interspecific physiological functioning will inform stand and landscape-level vegetation models for the region and can aid in the restoration and conservation of bottomland hardwood forests.

\section{Materials and Methods}

\subsection{Site Description}

The study was conducted within a bottomland hardwood forest in the John W. Starr Memorial Forest $\left(33^{\circ} 26^{\prime} 52.82^{\prime \prime} \mathrm{N}, 88^{\circ} 89^{\prime} 21.29^{\prime \prime} \mathrm{W}\right)$ located in east-central Mississippi. The study site is located on a minor stream bottom formed by Jones Creek, which is within the Noxubee River Watershed (HUC 03160108). The dominant soil type on this site is Urbo silt loam soils $(90 \%)$, which are somewhat impervious, making them susceptible to seasonal inundation [21]. The mean depth to the water table in the summer months is between 30 and $61 \mathrm{~cm}$ [21]. The tree species on the study site include, in order of abundance, pignut hickory (Carya glabra (Mill.) Sweet), willow oak (Quercus phellos), cherrybark oak (Quercus pagoda), sweetgum (Liquidambar styraciflua L.), swamp chestnut oak (Quercus michauxii), winged elm (Ulmus alata), green ash (Fraxinus pennsylvanica), American elm (Ulmus americana), shagbark hickory (Carya ovata), water oak (Quercus nigra), and sugarberry (Celtis laevigata Willdenow). Common understory species include greenbriar (Smilax spp. L.), paw paw (Asimina triloba (L.) Dunal), and American holly (Ilex opaca Aiton). 
The study site exhibited a typical climate for the region, with 30 year mean precipitation values from $1981-2010$ of $13.79 \mathrm{~cm} \mathrm{month}^{-1}$ in the winter and $10.49 \mathrm{~cm} \mathrm{month}^{-1}$ in the summer, and with mean temperatures of $6.8^{\circ} \mathrm{C}$ in winter and $26.5^{\circ} \mathrm{C}$ in the summer [22]. Due to the geographic position of the site and the lack of direct connections to steams or rivers, flooding in the dormant season was not the result of surface water overflow, but was instead a result of elevated water table levels and precipitation. The water table was above the soil surface for $\sim 30 \%$ of the site from January to April, 2017, resulting in standing water. The volumetric soil moisture content at the site was measured with three time domain reflectometry probes (CS616; Campbell Scientific Inc. Logan, UT, USA), and air temperature and relative humidity (used to calculate vapor pressure deficit; VPD) were measured with a Rotronic HC2S3 sensor (Campbell Scientific Inc.) located at mid-canopy height. Data from these environmental sensors were collected half-hourly with a CR1000 datalogger (Campbell Scientific Inc.). Soil moisture conditions from January to April 2017 were greater than $0.60 \mathrm{~cm}^{3} \mathrm{~cm}^{-3}$. Flooding exhibited high spatial variation in terms of standing water depth. Some areas of the site had $50+\mathrm{cm}$ of standing water for a majority of the dormant season; in other areas, the water table remained at sub-surface levels. The photosynthetic photon flux density (PPFD) was measured in a nearby canopy gap using a LI190SB quantum Sensor (LI-COR Biosciences Inc., Lincoln, NE, USA) and LI-COR Datalogger (LI 1400).

\subsection{Experimental Design and Tree-Level Characteristics for Intra-Crown Variability}

The study included three to five individuals per species of eight co-occurring bottomland hardwood species within an $1800 \mathrm{~m}^{2}$ plot area, with each tree representing an experimental unit. The study species included four oak species (cherrybark oak (CBO), swamp chestnut oak (SCO), willow oak (WO), and water oak (WAO)), two elm species (American elm (AE) and winged elm (WE)), one hickory (shagbark hickory (SH)), and one ash (green ash (GA)) (Table S1). Species were chosen based on their abundance in the overstory and midstory, and study individuals were chosen to cover a range in size for each species within the site (Table S1). We measured the total tree height and height to the base of the live crown in July 2017 using an Impulse 200 Rangefinder (Laser Technology Inc. Centennial, CO, USA). Crown radii from the base of the stem were measured from four azimuthal directions to obtain the mean crown width (Table S1).

For three study individuals per species, ten leaves or leaflets were collected from haphazard crown locations by either collecting recently fallen litterfall before leaf drying occurred or removing canopy leaves using a slingshot or shotgun from September to November 2017. Green ash individuals were excluded from this analysis due to difficulty in obtaining epidermal impressions from this species. For each leaf, stomatal lengths and stomatal densities were measured using epidermal impressions. A thin coat of clear nail polish was applied to the abaxial side of the leaf and placed on a microscope slide with a cover slip. Using a compound light microscope (Olympus Vanox, Waltham, MA, USA) and attached digital camera (AmScope FMA050, Irvine, CA, USA) ten leaf images each were obtained using the $20 \times$ and $40 \times$ objective lenses. ImageJ software version 1.48 (National Institutes of Health, Bethesda, MD, USA) was used for stomatal counts (using $20 \times$ images) to calculate stomatal density and to measure stomatal lengths (using $40 \times$ images for all stomata in the field of view) as the distance between the guard cell connection points. Measurements for each leaf or leaflet were averaged and leaf-level estimates were averaged to obtain tree-level estimates.

Tree-level sapflow data measured using Granier-style heat dissipation sensors inserted into the trunks of study trees were used to estimate seasonal, tree-level water use per unit leaf area for the 2017 growing season. More information on these data can be found in Kassahun [23]. To calculate the seasonal water use per unit leaf area, daily sapflow rates were summed over the course of the growing season and divided by tree-level leaf area estimated with an LAI 2000 leaf area meter (LI-COR Biosciences Inc.) and validated from litterfall trap proportions [23]. Measured daily sapflow rates for each individual were also compared with maximum daily photosynthetic photon flux density (PPFD) and the natural log of the mean daytime vapor pressure deficit (lnVPD) using a simple linear regression 
in Sigmaplot software version 13 (Systat Software, Inc. San Jose, CA, USA). The slope of these linear relationships for each study individual was used to identify the sapflow "response" to PPFD or lnVPD.

\subsection{Leaf-Level Photosynthetic Capacity for Inter-Species Comparison}

Over the course of a five-week period in June and July 2017, gas exchange measurements were obtained using a LI-COR 6400 Portable Photosynthesis System (LI-COR Biosciences Inc.). Efforts were made to measure the same individuals as in the tree-level leaf collection; however, if branches could not be reached with a pole pruner, other individuals within the study species were selected (Table S1). Gas exchange measurements were made during sunny mornings to avoid low light or afternoon water stress conditions that could induce stomatal closure. To obtain measurements, accessible branches in the lower crown of sample trees were cut using a $7.8 \mathrm{~m}$ long pole pruner and immediately placed into a water-filled bucket. Cut branches were recut under water to reduce embolisms and moved into a sunny location for gas exchange measurements, which were initiated within minutes of initially cutting branches. If leaves exhibited low stomatal conductance, likely as a result of cutting, a new branch was obtained and measured.

$\mathrm{A} / \mathrm{C}_{\mathrm{i}}$ curves (carbon assimilated $(\mathrm{A}) /$ internal $\mathrm{CO}_{2}$ concentration $\left(\mathrm{C}_{\mathrm{i}}\right)$ ) were created under saturating light conditions $\left(1500 \mu \mathrm{mol} \mathrm{m} \mathrm{m}^{-2} \mathrm{~s}^{-1}\right)$. Ambient levels of $\mathrm{CO}_{2}$ in the chamber were set at $400 \mathrm{ppm}$, then lowered to 300, 200, 100, and lastly 50 ppm before being increased to 400,600, and finally 800 ppm. The leaf temperature was set to match the ambient temperature in the environment. Instantaneous photosynthetic rates, transpiration rates and stomatal conductance were estimated from initial values at ambient $\mathrm{CO}_{2}$ concentrations. The ratio of photosynthetic rates to the transpiration rate or stomatal conductance was used to calculate the instantaneous water use efficiency (WUE) and instantaneous intrinsic water use efficiency (iWUE), respectively. $A / C_{i}$ curve data were imported into a curve fitting utility developed by Sharkey et al. [24], which was used to estimate the maximum Rubisco-limited carboxylation rate $\left(\mathrm{V}_{\mathrm{Cmax}}\right)$, maximum electron transport-limited carboxylation rate $\left(\mathrm{J}_{\max }\right)$, and triose phosphate utilization limited carboxylation rate (TPU). To fit $\mathrm{V}_{\mathrm{Cmax}}, \mathrm{J}_{\max }$, and TPU, the $\mathrm{R}_{\text {day }}$ (daytime respiration) parameter was restricted to values less than $20 \mu \mathrm{mol} \mathrm{m}{ }^{-2} \mathrm{~s}^{-1}$ and the $\mathrm{g}_{\mathrm{m}}$ (mesophyll conductance) parameter was restricted to values less than $5 \mu \mathrm{mol} \mathrm{m} \mathrm{m}^{-2} \mathrm{~s}^{-1} \mathrm{~Pa}^{-1}$. Parameter combinations that minimized the sums of squares error between modeled fits and measured data were then scaled to a common temperature of $25^{\circ} \mathrm{C}$.

\subsection{Leaf-Level Nutrients, Isotopes and Foliar Anatomy for Comparison Within and Across Species}

Leaves (or leaflets in the case of green ash and shagbark hickory) measured for gas exchange, as well as three replicate leaves from the same branch, were placed in zip-top bags, put into a cooler, and returned to the lab for leaf anatomic, nutrient and isotope analysis. Fresh leaf (or leaflet) areas used for photosynthetic measurements were measured using a LI-COR 31000 leaf area meter (LI-COR Biosciences Inc.). Leaves were then dried for at least $72 \mathrm{~h}$ at $60{ }^{\circ} \mathrm{C}$ and weighed. Leaf mass per unit area (LMA) was calculated as the ratio of dry leaf mass and fresh leaf area. Dried leaves were then ground to a fine powder (less than $250 \mu \mathrm{m}$ ), and about $4 \mathrm{mg}$ of sample was weighed and placed into tin capsules. Samples were sent to the University of California Davis Stable Isotope Facility, and estimates of leaf carbon and nitrogen concentrations, $\delta^{13} \mathrm{C}$ and $\delta^{15} \mathrm{~N}$ isotopes ratios were obtained using a PDZ Europa ANCA-GSL elemental analyzer interfaced to a PDZ Europa 20-20 isotope ratio mass spectrometer (Sercon Ltd., Cheshire, UK). Nitrogen concentrations were multiplied by LMA to scale data on a per unit leaf area basis $\left(\mathrm{N}_{\text {area }} ; \mathrm{g} \mathrm{m}^{-2}\right)$ in order to compare between species. Photosynthetic nitrogen use efficiency (PNUE; $\mu \mathrm{mol} \mathrm{CO}_{2} \mathrm{~g}^{-1} \mathrm{~N} \mathrm{~s}^{-1}$ ) was calculated as the ratio of photosynthetic rate measured at saturating light and ambient $\mathrm{CO}_{2}$ and $\mathrm{N}_{\text {area }}$. For leaves measured for gas exchange, stomatal lengths and densities were estimated using epidermal leaf impressions using similar methods as above. Vein densities were also estimated on gas exchange leaves from epidermal impressions on ten images per leaf collected using the $10 \times$ objective lens. On each image, the area occupied by veins was measured and divided by total image area. 
To determine the resorption rates for nitrogen for each measured species, ten $0.75 \mathrm{~m}^{2}$ litterfall traps were placed strategically around the field site near measured individuals. Litterfall was collected biweekly from October 2017 to January 2018 and sorted by species. Three subsamples of each species' litterfall were selected, dried at $60{ }^{\circ} \mathrm{C}$ and ground to a fine powder, and approximately $3 \mathrm{mg}$ of powder was placed into tin capsules. Litterfall samples were analyzed for carbon and nitrogen concentration using an ECS 4010 CHNS-O Analyzer (Costech Analytical Technologies, Inc. Valencia, CA, USA). The mean litterfall $\mathrm{N}$ concentration for each species was subtracted from live leaf $\mathrm{N}$ concentration, and this difference was divided by the live leaf $\mathrm{N}$ concentration to calculate $\mathrm{N}$ resorption (\%).

\subsection{Soil Nitrogen}

Soil samples were collected in 20 random locations from across the site once per month during the period of inundation for the site (December-April) and again in July and October 2017 to determine seasonal differences in soil nitrogen content. An approximately $20 \mathrm{~cm}$ deep soil core was collected at each location and divided into the top $(0-5 \mathrm{~cm})$ and bottom $(5-20 \mathrm{~cm})$ layer. Soils were placed in zip-top bags and returned to the lab. Soils were analyzed visually to determine clay and organic matter categorizations. In addition, a subset of each sample was weighed upon returning to the lab, placed in a drying oven at $105{ }^{\circ} \mathrm{C}$ for approximately 3 days, and its dry weight was determined to calculate the gravimetric soil moisture content. In addition, for a subset of soil core samples, the bulk density was determined as the ratio of dry soil mass divided by soil volume and averaged 1.15 to $1.38 \mathrm{~g} \mathrm{~cm}^{-3}$ depending on soil texture. Soil bulk densities were used to calculate volumetric soil moisture contents. These calculated volumetric soil moisture contents were compared with the maximum volumetric moisture contents measured during this period using time domain reflectometry probes (see above) to determine if samples were saturated or unsaturated during the time of collection.

Soil samples from each soil collection date were aggregated based on the soil moisture level and content of clay/organic matter for a total of eight samples per month per soil depth (16 monthly samples total) across a range of soil moistures and textures. Soils were extracted using the nitrate and exchangeable ammonium nitrogen procedure [25]. Extracted samples were stored at $-20{ }^{\circ} \mathrm{C}$ until analysis. Samples were measured in February 2018 using a DR-2800 Portable Spectrophotometer (Hach Company, Loveland, CO, USA) and Nitrate, TNT+ LR Vial Test Kits as well as Ammonia, TNT+ LR Vial Test Kits (Hach Company). Standards and blanks were created with each extraction in order to account for any error. Due to possible nitrogen transformations during sample storage, total ammonia and nitrate concentrations were summed in order to calculate total inorganic nitrogen concentrations within each sample.

\subsection{Statistical Analysis}

For comparisons of photosynthetic capacity, leaf isotopes, C and N concentrations, and anatomy, data were averaged to the individual tree level and compared across genera or species using analysis of variance (ANOVA) in R version 3.3.2 [26]. First, ANOVA was used to determine if significant differences existed between species in the Quercus and Ulmus genera. If species were statistically similar within genera, comparisons were made across genera using ANOVA. Tukey pairwise comparisons were made if genera were statistically different from one another. If species differed significantly within genera, then comparisons were made across all species in the study using ANOVA and Tukey pairwise comparisons. Diversity quotients were calculated as the maximum species mean value divided by the minimum species mean value. Linear regressions between leaf-level physiological parameters or between tree-level anatomical characteristics, and water use properties were fitted and statistical results calculated using Sigmaplot 13.0 software (Systat Software, Inc.) across all study individuals. Principal component analysis was performed in $\mathrm{R}$ using the prcomp function with all variables scaled and zero centered.

To compare the variation in leaf anatomical properties across individual tree crowns and species and determine the data range captured by leaf physiological measurements, boxplots were created 
using Sigmaplot. The whole-tree canopy variability for each species was plotted using individual leaf means from tree-level leaf collections for each species. Plasticity quotients were calculated by dividing the maximum measured leaf values by minimum values. Stomatal parameters from whole tree collections were compared with leaves collected for gas exchange using ANOVA. Soil nitrogen data were compared across months of the dormant season (December 2016-April 2017) using ANOVA for unsaturated or saturated soils.

\section{Results}

\subsection{Comparison of Parameters within and across Species}

In terms of photosynthetic capacity parameters, $\mathrm{V}_{\mathrm{Cmax}}$ was similar within genera (for oaks and elms) but differed significantly across genera, with green ash having about $34 \%$ greater $V_{C m a x}$ (Table 1). Regarding J Jax, elm species differed significantly from one another; therefore, species-level comparisons were made and differed significantly. Ambient photosynthetic and transpiration rates were similar within genera but differed significantly across genera, with green ash exhibiting higher photosynthetic rates and $60 \%-180 \%$ greater transpiration rates compared to other genera. Water use efficiencies (WUEs) were similar within genera but differed significantly across genera, with green ash exhibiting a lower WUE than oaks and elms but being similar to shagbark hickory (Table 1). Regarding $\delta^{13} \mathrm{C}$ (an integrated measure of water use efficiency), elms had significantly less negative $\delta^{13} \mathrm{C}$ values (i.e., they were more water-use efficient) compared with oaks and green ash (Table 1). In terms of nutrients, species differed significantly within the oak genus and across all species. Shagbark hickory exhibited the highest leaf $\mathrm{N}$ concentrations, and willow oak and American elm exhibited the lowest. However, photosynthetic nitrogen use efficiency (PNUE) was statistically similar within and across genera (Table 1). Mean $\mathrm{N}$ resorption rates differed significantly within both the oak and elm genera and across species with willow oak, green ash and winged elm exhibiting the largest $\mathrm{N}$ resorption rates and water oak and American elm exhibiting the smallest (Table 1).

Regarding leaf anatomical parameters, LMA was similar within and across genera (Table 2). However, in terms of stomatal parameters, species differed significantly within the oak genus and across all study species, with stomatal lengths being longest in green ash and the elms, intermediate in the oaks and smallest in shagbark hickory. Conversely, cherrybark and swamp chestnut oak exhibited the highest stomatal densities; water oak, willow oak and winged elm were intermediate; and stomatal densities in shagbark hickory, American elm and green ash were the lowest (Table 2). In terms of vein density, species differed within the oak genus and across all species in the study, with willow oak and winged elm exhibiting the highest vein densities; cherrybark oak, water oak, shagbark hickory and American elm being intermediate; and green ash exhibiting the lowest vein densities (Table 2).

Parameters derived from $\mathrm{A} / \mathrm{C}_{\mathrm{i}}$ curves $\left(\mathrm{V}_{\mathrm{Cmax}}, \mathrm{J}_{\max }\right)$ as well as photosynthetic rates had diversity quotients (maximum value/minimum value) ranging from 1.3 to 1.7 , meaning that maximum values were $30 \%$ to $70 \%$ higher than minimum values across species (Table 3 ). Similar diversity ranges were seen in LMA and leaf nitrogen parameters, which had diversity quotients of 1.3 to 1.5 across species. However, leaf-level water use parameters including transpiration and stomatal conductance showed greater variability, with diversity quotients of 3.3 and 3.6, respectively, meaning that maximal species had over three times higher transpiration rates than minimal water use species (Table 3). Likewise, diversity quotients for water use efficiency parameters were around 2, while photosynthetic nitrogen use efficiency had a diversity quotient of about 1.5. Leaf anatomical parameters displayed the widest diversity across species, with the stomatal density and vein density having diversity quotients of 5.1 and 3.4 , respectively (Table 3). 
Table 1. Mean (standard error in parentheses) leaf carbon assimilation, water use and nutrient parameters for bottomland hardwood study species.

\begin{tabular}{|c|c|c|c|c|c|c|c|c|}
\hline & $\begin{array}{c}\text { Cherrybark } \\
\text { Oak }\end{array}$ & $\begin{array}{c}\text { Swamp } \\
\text { Chestnut Oak }\end{array}$ & Water Oak & Willow Oak & Green Ash & $\begin{array}{c}\text { Shagbark } \\
\text { Hickory }\end{array}$ & $\begin{array}{l}\text { American } \\
\text { Elm }\end{array}$ & Winged Elm \\
\hline 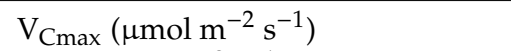 & $84.7(6.1)^{\text {B }}$ & $90.7(3.9)^{\mathrm{B}}$ & $81.2(4.9)^{\mathrm{B}}$ & $80.3(8.4)^{B}$ & $118.5(2.5)^{\mathrm{A}}$ & $97.7(5.0)^{\mathrm{B}}$ & $97.1(2.6)^{B}$ & $88.1(4.7)^{\mathrm{B}}$ \\
\hline $\mathrm{J}_{\max }\left(\mu \mathrm{mol} \mathrm{m} \mathrm{m}^{-2} \mathrm{~s}^{-1}\right)$ & $132.8(4.4)^{a b}$ & $131.2(7.1)^{a b}$ & $111.3(5.5)^{b}$ & $134.3(10.9)^{a b}$ & $146.9(2.2)^{\mathrm{a}}$ & $121.3(9.6)^{a b}$ & $139.6(0.8)^{a b}$ & $120.9(6.1)^{a b}$ \\
\hline Photosynthetic rate $\left(\mu \mathrm{mol} \mathrm{m}{ }^{-2} \mathrm{~s}^{-1}\right)$ & $5.4(1.6)^{\mathrm{B}}$ & $5.3(0.5)^{B}$ & $6.0(0.7)^{B}$ & $5.4(0.6)^{\mathrm{B}}$ & $9.1(1.0)^{\mathrm{A}}$ & $8.0(0.5) \mathrm{AB}$ & $6.0(1.4)^{\mathrm{B}}$ & $6.5(1.2)^{B}$ \\
\hline Transpiration rate $\left(\mathrm{mmol} \mathrm{m}^{-2} \mathrm{~s}^{-1}\right)$ & $1.6(0.5)^{\mathrm{B}}$ & $1.5(0.2)^{\mathrm{B}}$ & $1.8(0.3)^{\mathrm{B}}$ & $2.2(0.4)^{\mathrm{B}}$ & $4.9(0.9)^{\mathrm{A}}$ & $3.0(0.3)^{\mathrm{B}}$ & $1.7(0.3)^{\mathrm{B}}$ & $1.9(0.3)^{\mathrm{B}}$ \\
\hline Water use efficiency $\left(\mu \mathrm{mol} \mathrm{mmol}{ }^{-1}\right)$ & $3.4(0.3)^{\mathrm{A}}$ & $3.5(0.2) \mathrm{A}$ & $3.4(0.4) \mathrm{A}$ & $2.7(0.5)^{\mathrm{A}}$ & $1.9(0.2)^{B}$ & $2.8(0.3) \mathrm{AB}$ & $3.4(0.2) \mathrm{A}$ & $3.4(0.1) \mathrm{A}$ \\
\hline Stomatal conductance $\left(\mathrm{mol} \mathrm{m}^{-2} \mathrm{~s}^{-1}\right)$ & $0.07(0.02)^{\mathrm{B}}$ & $0.07(0.01)^{\mathrm{B}}$ & $0.08(0.02)^{B}$ & $0.10(0.02)^{\mathrm{B}}$ & $0.25(0.07)^{\mathrm{A}}$ & $0.14(0.01) \mathrm{AB}$ & $0.08(0.02)^{\mathrm{B}}$ & $0.08(0.02)^{\mathrm{B}}$ \\
\hline Intrinsic WUE $(\mu \mathrm{mol} \mathrm{mol}-1)$ & $84.3(8.1)^{\mathrm{A}}$ & $80.0(7.4)^{\mathrm{A}}$ & $85.2(14.6)^{\mathrm{A}}$ & $65.3(14.9)^{\mathrm{A}}$ & $42.6(8.0)^{B}$ & $56.5(4.4) \mathrm{AB}$ & $81.0(5.1)^{\mathrm{A}}$ & $82.3(5.0)^{\mathrm{A}}$ \\
\hline$\delta^{13} \mathrm{C}(\%$ o $)$ & $-30.9(0.7)^{B}$ & $-30.5(0.2)^{B}$ & $-30.4(0.5)^{B}$ & $-30.4(0.5)^{\mathrm{B}}$ & $-30.1(0.1) \mathrm{AB}$ & $-29.6(0.4) \mathrm{AB}$ & $-29.8(0.2)^{\mathrm{A}}$ & $-29.3(0.3)^{\mathrm{A}}$ \\
\hline $\mathrm{N}$ concentration $(\%)$ & $2.7(0.03)^{a}$ & $2.4(0.1)^{a b}$ & $2.3(0.1)^{a b}$ & $2.0(0.1)^{b}$ & $2.6(0.1)^{a b}$ & $2.8(0.1)^{\mathrm{a}}$ & $2.1(0.1)^{b}$ & $2.3(0.2)^{a b}$ \\
\hline $\mathrm{C} / \mathrm{N}$ ratio & $17.9(0.3)^{b c}$ & $18.4(0.3)^{b c}$ & $20.5(1.1)^{b}$ & $24.5(1.1)^{\mathrm{a}}$ & $17.0(0.05) b c$ & $16.1(0.3)^{c}$ & $20.0(0.6)^{b c}$ & $18.4(0.9)^{b c}$ \\
\hline PNUE $\left(\mu \mathrm{mol} \mathrm{g}{ }^{-1} \mathrm{~N} \mathrm{~s}^{-1}\right)$ & $4.6(1.0)$ & $4.4(0.3)$ & $4.9(2.1)$ & $5.1(0.4)$ & $6.8(0.3)$ & $6.8(0.4)$ & $6.0(1.9)$ & $6.0(1.1)$ \\
\hline $\mathrm{N}$ resorption $(\%)$ & $47.3(0.5)^{a b}$ & $53.4(2.8)^{\mathrm{ab}}$ & $45.0(2.7)^{b}$ & $57.2(2.3)^{\mathrm{a}}$ & $58.5(1.7)^{\mathrm{a}}$ & $55.7(0.8)^{a b}$ & $44.2(2.78)^{b}$ & $57.4(3.1)^{\mathrm{a}}$ \\
\hline$\delta^{15} \mathrm{~N}(\% o)$ & $0.64(0.2)$ & $0.66(0.010)$ & $0.77(0.92)$ & $0.40(0.5)$ & $1.68(0.008)$ & $0.97(0.02)$ & $0.67(1.0)$ & $-0.79(0.7)$ \\
\hline
\end{tabular}

${ }^{1}$ Capital letters indicate significant differences at the genus level, lower case letters indicate significant differences at the species level at $P<0.05$. WUE: water use efficiency; PNUE: photosynthetic nitrogen use efficiency.

Table 2. Mean (standard error in parentheses) leaf anatomical parameters for bottomland hardwood study species.

\begin{tabular}{|c|c|c|c|c|c|c|c|c|}
\hline & $\begin{array}{c}\text { Cherrybark } \\
\text { Oak }\end{array}$ & $\begin{array}{c}\text { Swamp } \\
\text { Chestnut Oak }\end{array}$ & Water Oak & $\begin{array}{l}\text { Willow } \\
\text { Oak }\end{array}$ & Green Ash & $\begin{array}{c}\text { Shagbark } \\
\text { Hickory }\end{array}$ & $\begin{array}{l}\text { American } \\
\text { Elm }\end{array}$ & $\begin{array}{l}\text { Winged } \\
\text { Elm }\end{array}$ \\
\hline Leaf mass per area $\left(\mathrm{g} \mathrm{m}^{-2}\right)$ & $56.2(0.8)$ & $48.5(3.9)$ & $62.7(10.0)$ & $61.6(3.6)$ & $43.8(0.8)$ & $42.6(1.4)$ & $51.6(8.3)$ & $47.9(1.8)$ \\
\hline Leaf (or leaflet) area $\left(\mathrm{cm}^{2}\right)$ & $103.0(15.0)^{a b}$ & $143.3(11.9)^{\mathrm{a}}$ & $32.0(14.2)^{c}$ & $29.3(3.8)^{c}$ & $56.4(9.2) b c$ & $148.9(33.5)^{\mathrm{a}}$ & $44.5(1.1) \mathrm{bc}$ & $17.9(1.4)^{\mathrm{c}}$ \\
\hline Stomatal length $(\mu \mathrm{m})$ & $13.0(0.1)^{\mathrm{c}}$ & $12.7(0.2)^{\mathrm{cd}}$ & $13.1(0.2)^{\mathrm{c}}$ & $12.5(0.1)^{\mathrm{c}}$ & $17.2(0.2)^{a}$ & $11.3(0.3)^{d}$ & $15.7(0.2)^{\mathrm{a}}$ & $14.1(0.3)^{b}$ \\
\hline Stomatal density $\left(\mathrm{mm}^{-2}\right)$ & $786(16.9)^{a}$ & $713(30.7)^{\mathrm{a}}$ & $506(14.1)^{c}$ & $608(11.0)^{b}$ & $149(19.0)^{\mathrm{e}}$ & $388(12.4)^{d}$ & $254(10.2)^{\mathrm{e}}$ & $508(18.9)^{c}$ \\
\hline Vein density $(\%)$ & $16.2(1.1)^{\mathrm{ab}}$ & $13.4(2.6)^{b c}$ & $13.1(1.3)^{a b c}$ & $20.4(1.0)^{\mathrm{a}}$ & $6.2(1.3)^{c}$ & $15.6(1.8)^{\mathrm{ab}}$ & $15.9(1.0)^{\mathrm{ab}}$ & $20.9(2.3)^{\mathrm{a}}$ \\
\hline
\end{tabular}

${ }^{1}$ Lower-case letters indicate significant differences at the species level at $P<0.05$. 
Table 3. Diversity quotients (maximum value/minimum value) across study species.

\begin{tabular}{lc}
\hline \multicolumn{1}{c}{ Parameters } & Diversity Quotients \\
\hline $\mathrm{V}_{\mathrm{Cmax}}$ & 1.5 \\
$\mathrm{~J}_{\max }$ & 1.3 \\
Photosynthetic rate & 1.7 \\
Transpiration rate & 3.3 \\
Water use efficiency & 1.8 \\
Stomatal conductance & 3.6 \\
Intrinsic WUE & 2.0 \\
$\delta^{13} \mathrm{C}$ & 1.0 \\
$\mathrm{~N}$ concentration & 1.4 \\
$\mathrm{C} / \mathrm{N}$ ratio & 1.5 \\
PNUE & 1.5 \\
$\mathrm{~N}$ resorption & 1.3 \\
Leaf mass per area & 1.5 \\
Leaf or leaflet area & 8.3 \\
Stomatal length & 1.7 \\
Stomatal density & 5.1 \\
Vein density & 3.4 \\
\hline
\end{tabular}

\subsection{Correlations between Physiological Parameters, Leaf Anatomy and Nutrients}

Across all study species in this bottomland hardwood forest, several leaf anatomic and nutrient parameters were significantly correlated with $\mathrm{V}_{\mathrm{Cmax}}$ (Figure 1). $\mathrm{V}_{\mathrm{Cmax}}$ was negatively correlated with leaf anatomical parameters related to water transport and resistance, including a slight correlation with LMA $\left(P=0.017 ; r^{2}=0.16\right.$; Figure $\left.1 \mathrm{a}\right)$ and stronger correlations with vein density $(P=0.014$; $r^{2}=0.22$; Figure $\left.1 b\right)$ and stomatal density $\left(P=0.0032 ; r^{2}=0.29\right.$; Figure $\left.1 c\right) . V_{C \max }$ was also weakly, but significantly, correlated with leaf parameters related to nitrogen content, including a positive correlation with $\delta^{15} \mathrm{~N}\left(P=0.047 ; r^{2}=0.17\right.$; Figure $\left.1 \mathrm{~d}\right)$ and a negative correlation with leaf $\mathrm{C} / \mathrm{N}$ ratio $\left(P=0.043 ; r^{2}=0.17\right.$; Figure 1e).

In terms of tree-level seasonal water use parameters, whole crown mean stomatal density was the only parameter that exhibited significant relationships, being negatively correlated with seasonal water use per unit leaf area $\left(P=0.008 ; r^{2}=0.32\right.$, Figure $\left.2 a\right)$ and weakly negatively correlated with tree-level response to $\operatorname{lnVPD}$ (change in daily sapflow/change in mean daytime $\ln V P D ; P=0.046 ; r^{2}=0.19$; Figure $2 b$ ) and response to PPFD (change in daily sapflow/change in maximum daily PPFD; $P=0.029$; $r^{2}=0.23$; Figure 2c). Whole crown mean stomatal density was also significantly, positively correlated with tree diameter at breast height $\left(\mathrm{DBH} ; P=0.039 ; r^{2}=0.21\right)$ and tree height $\left(P=0.003 ; r^{2}=0.38\right.$; Figure S1). For leaf-level parameters, stomatal densities were significantly, positively correlated with $\operatorname{WUE}\left(P=0.017 ; r^{2}=0.20\right.$; Figure 2d).

Regarding photosynthetic nitrogen use efficiency (PNUE), LMA was the only leaf anatomic parameter that exhibited a significant relationship across all species, exhibiting a strong negative correlation $\left(P=0.0004 ; r^{2}=0.44\right.$; Figure $\left.3 a\right)$. PNUE was strongly, positively correlated with leaf-level water use parameters including stomatal conductance $\left(P=0.0002 ; r^{2}=0.47\right)$ and transpiration rates $\left(P=0.0001 ; r^{2}=0.38\right.$; data not shown). Therefore, water and nitrogen resource use efficiencies exhibited a tradeoff, with PNUE being weakly, negatively correlated with intrinsic water use efficiency (iWUE; $P=0.04 ; r^{2}=0.18$; Figure $\left.3 b\right)$. However, PNUE was positively correlated with $\delta^{13} C(P=0.016$; $r^{2}=0.24$; Figure $3 c$ ) —another metric for iWUE representative of larger spatial and temporal scales than instantaneous leaf-level gas exchange measurements. Leaf-level $\delta^{13} \mathrm{C}$ was not correlated with either WUE or iWUE estimated from instantaneous gas exchange (data not shown). 

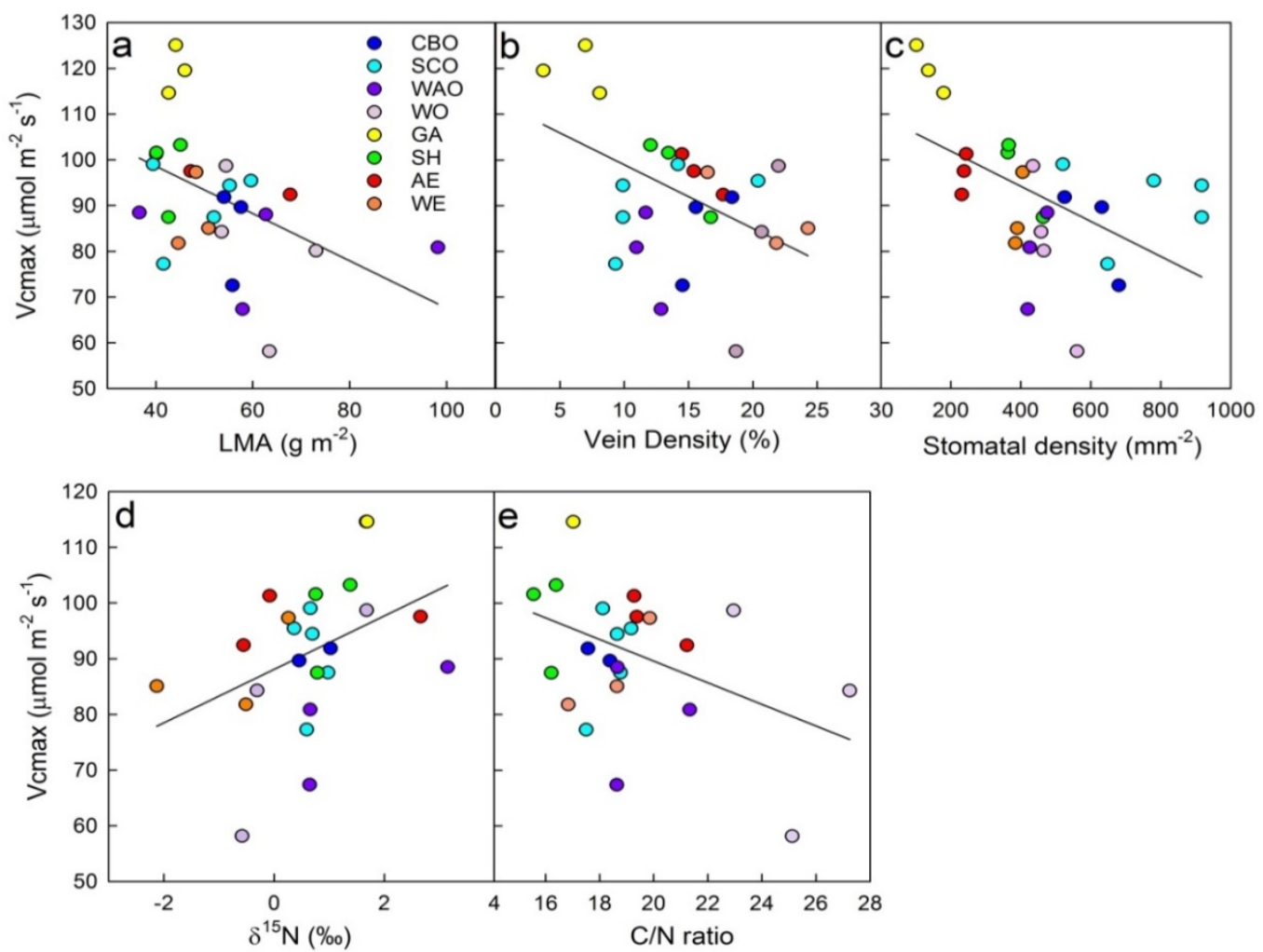

Figure 1. Significant correlations between Rubisco-limited carboxylation rate $\left(\mathrm{V}_{\mathrm{Cmax}} ; \mu \mathrm{mol} \mathrm{m} \mathrm{m}^{-2} \mathrm{~s}^{-1}\right)$ and leaf parameters including (a) leaf mass per unit area $\left(\mathrm{LMA} ; \mathrm{g} \mathrm{m}^{-2}\right),(\mathbf{b})$ vein density (\%), (c) stomatal density $\left(\mathrm{mm}^{-2}\right),(\mathbf{d}) \delta^{15} \mathrm{~N}(\%$ o), and (e) C/N ratio. Dark blue circles = cherrybark oak (CBO), light blue circles = swamp chestnut oak (SCO), dark purple circles = water oak (WAO), light purple circles = willow oak $(\mathrm{WO})$, yellow circles $=$ green ash $(\mathrm{GA})$ green circles $=$ shagbark hickory $(\mathrm{SH})$, red circles = American elm (AE), orange circles = winged elm $(\mathrm{WE})$.

For the principal component analysis of measured physiological, anatomical and biochemical parameters, PC1 and PC2 explained about $45 \%$ of the variation in the data. PC1 primarily captured the variation in photosynthetic capacity and resource use, exhibiting positive loading with photosynthetic rates, water use in terms of stomatal conductance and leaf $\mathrm{N}$ content. However, PC1 also exhibited positive loading with PNUE but negative loading with WUE parameters as well as LMA and the leaf $\mathrm{CN}$ ratio (Figure 4). PC2 primarily captured the variation in leaf anatomical parameters exhibiting positive loading with stomatal length, vein density and $\delta^{13} \mathrm{C}$, and negative loading with stomatal density and leaf area (Figure 4). For the measured individuals, green ash and shagbark hickory tended to group together towards the right, positive region of PC1, exhibiting high photosynthetic rates, stomatal conductance and PNUE but low water use efficiencies (Figure 4). Elms were located throughout PC1 with a variety of physiological functioning, but tended to group along the upper, positive region of PC2, exhibiting longer stomata and higher vein densities but smaller leaves and lower stomatal densities (Figure 4). Oaks also exhibited variation in PC1 and physiological functioning. However, willow oaks were located on the upper, positive region of PC2, exhibiting small leaves and high vein densities, while swamp chestnut oak and cherrybark oak tended to be located on the lower, negative region of PC2, exhibiting larger leaves and higher stomatal densities (Figure 4). 


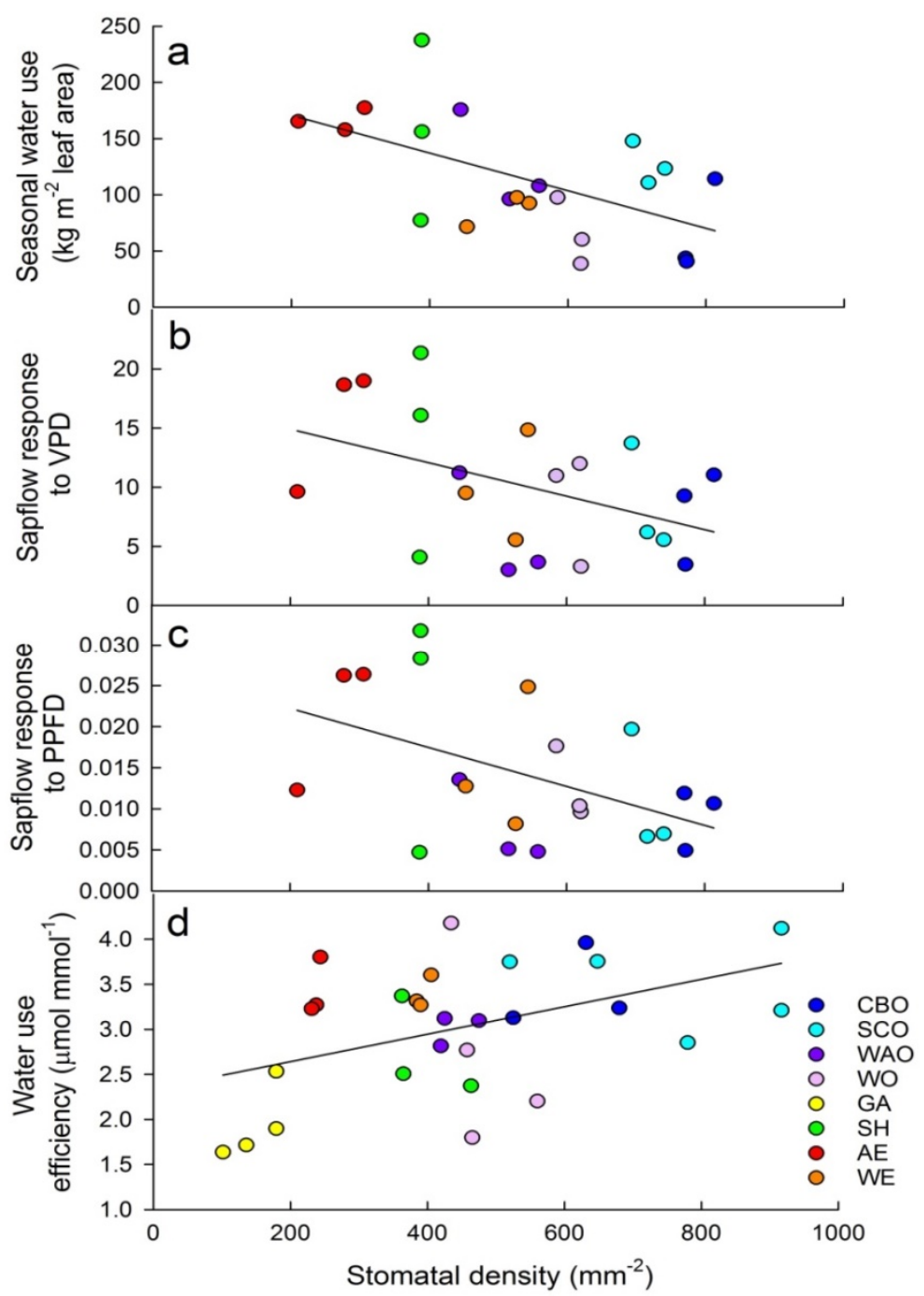

Figure 2. Mean whole crown-level stomatal density $\left(\mathrm{mm}^{-2}\right)$ vs. (a) individual water use across the growing season $\left(\mathrm{kg} \mathrm{H}_{2} \mathrm{O} \mathrm{m}^{-2}\right.$ leaf area), (b) slope of the relationship between daily sapflow and mean daytime vapor pressure deficit ("sapflow response to VPD"), (c) slope of the relationship between daily sapflow and maximum daily photosynthetic photon flux density ("sapflow response to PPFD") and (d) leaf-level stomatal density $\left(\mathrm{mm}^{-2}\right)$ vs. water use efficiency $\left(\mu \mathrm{mol} \mathrm{CO} \mathrm{COmol}^{-1} \mathrm{H}_{2} \mathrm{O}\right)$ in leaves measured for gas exchange. Dark blue circles = cherrybark oak (CBO), light blue circles = swamp chestnut oak (SCO), dark purple circles = water oak (WAO), light purple circles = willow oak (WO), yellow circles $=$ green ash $(\mathrm{GA})$ green circles = shagbark hickory $(\mathrm{SH})$, red circles = American elm $(\mathrm{AE})$, orange circles $=$ winged elm $(\mathrm{WE})$. 


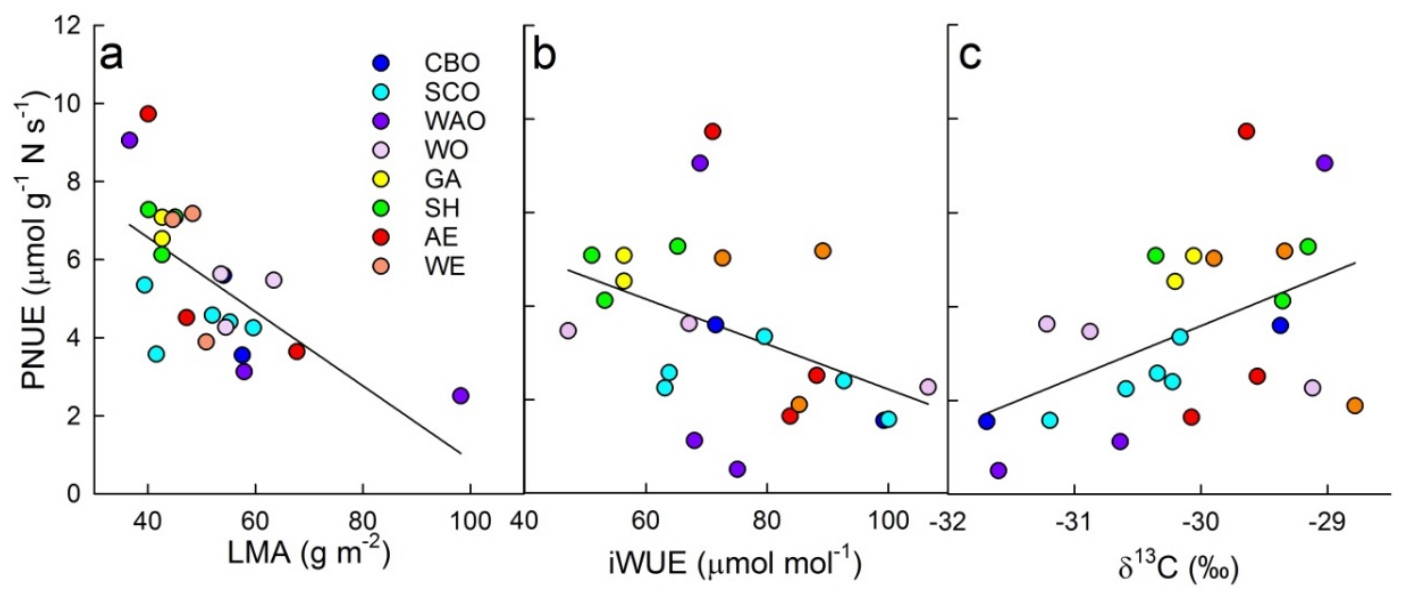

Figure 3. Significant correlations between photosynthetic nitrogen use efficiency (PNUE; $\mu \mathrm{mol} \mathrm{g}^{-1} \mathrm{~N}^{-1}$ ) and leaf anatomical and physiological variables including (a) leaf mass per unit area (LMA; $\mathrm{g} \mathrm{m}^{-2}$ ), (b) intrinsic water use efficiency (iWUE; $\mu \mathrm{mol} \mathrm{mol}^{-1}$ ) and (c) $\delta^{13} \mathrm{C}(\%$ ). Dark blue circles = cherrybark oak $(\mathrm{CBO})$, light blue circles $=$ swamp chestnut oak $(\mathrm{SCO})$, dark purple circles $=$ water oak $(\mathrm{WAO})$, light purple circles $=$ willow oak $(\mathrm{WO})$, yellow circles $=$ green ash (GA) green circles $=$ shagbark hickory $(\mathrm{SH})$, red circles = American elm $(\mathrm{AE})$, orange circles $=$ winged elm $(\mathrm{WE})$.

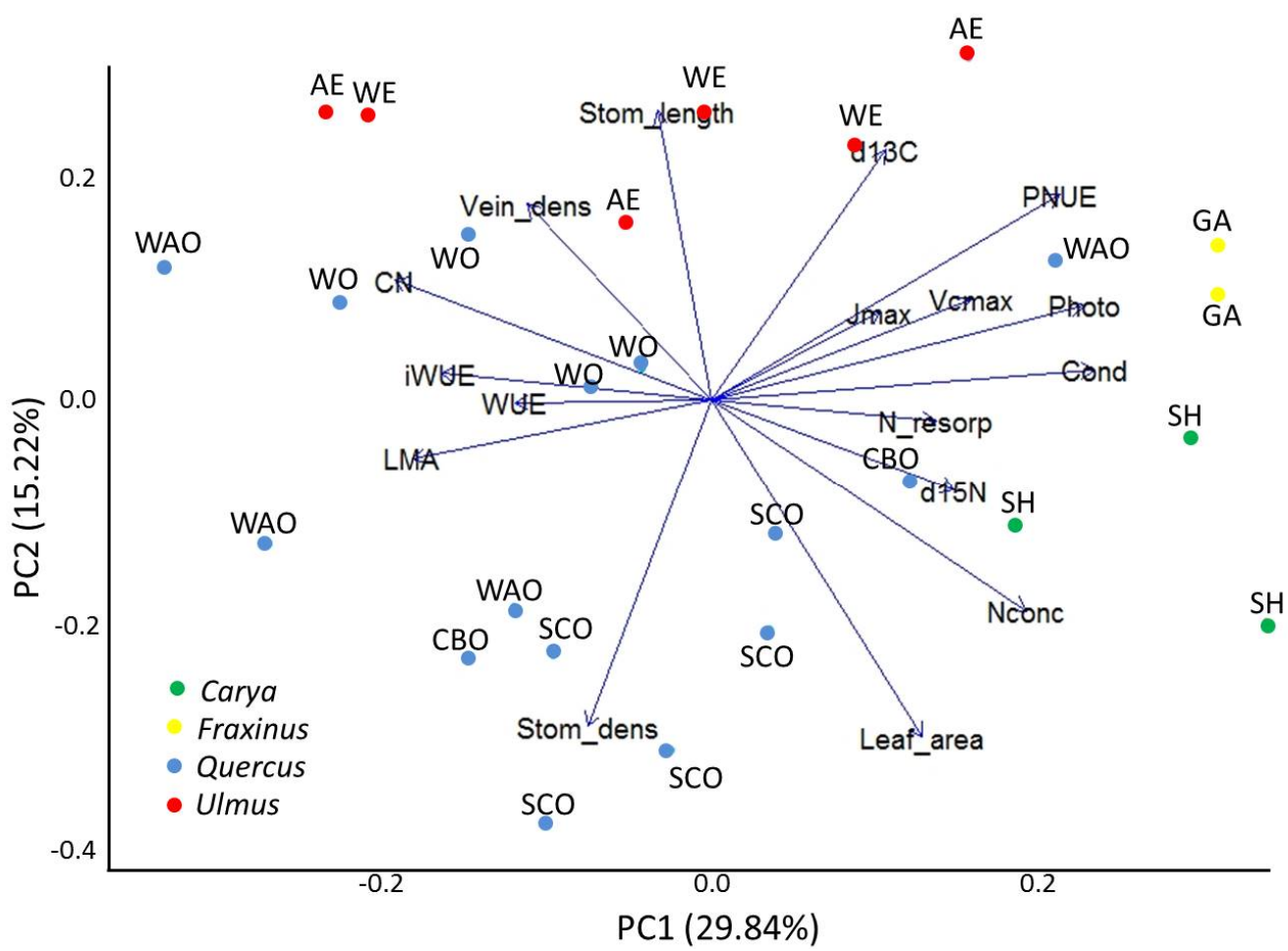

Figure 4. Contributions of selected variables to the first principal component (PC1) and second principal component (PC2) and data points corresponding to genera including Fraxinus (yellow circles; green ash (GA)), Carya (green circles; shagbark hickory (SH)), Quercus (blue circles; cherrybark oak (CBO), swamp chestnut oak (SCO), water oak (WAO), willow oak (WO)), and Ulmus (red circles; American elm (AE), winged elm (WE)) species.

\subsection{Within Crown and Intra-Species Variation in Stomatal Properties}

Plasticity quotients (maximum/minimum leaf value) in this study were larger for stomatal density than for stomatal length, with oaks and American elm exhibiting the lowest plasticity in stomatal density (1.5-2.0) and shagbark hickory and winged elm displaying greater plasticity (2.2 and 2.7 , respectively). 
In general, the standard deviation of stomatal density in leaves collected throughout tree crowns tended to increase with mean stomatal density; however, the results were only marginally significant $(P=0.08)$. Cherrybark oak and willow oak leaves measured for gas exchange had significantly lower stomatal densities than leaves from whole crown collections, with water oak and winged elm being marginally, significantly lower (Figure 5a). All other species did not differ significantly. In terms of stomatal length, plasticity quotients were under two for all measured species and were lowest in the oaks and American elm (1.3 to 1.4), with winged elm and shagbark hickory displaying greater plasticity (1.5 and 1.9, respectively). The canopy-level standard deviation in stomatal lengths within species was not correlated with mean stomatal lengths. Swamp chestnut oak, water oak, American elm and winged elm leaves measured for gas exchange had stomatal lengths that were significantly longer than whole-crown leaf collections (Figure 5b), and all other species did not differ significantly.



Figure 5. Boxplots of (a) mean stomatal densities $\left(\mathrm{mm}^{-2}\right)$ and $(\mathbf{b})$ mean stomatal lengths $(\mu \mathrm{m})$ from leaves collected from throughout the crowns of study individuals ( $n=30$; gray boxes) and from leaves measured for photosynthetic gas exchange $(n=3-5$; red boxes). Red asterisks indicate that gas exchange (photosynthesis) leaves differed significantly from whole-crown collections at $P<0.05$; red dots indicate significant differences at $P<0.1$. Leaves were not collected from green ash whole crowns due to the difficulty in obtaining epidermal impressions.

\subsection{Soil Nitrogen During Inundation Periods}

For unsaturated soils collected during the winter and early spring dormant period, the nitrogen content differed significantly by month $(P=0.005)$, particularly for March and April 2017 which differed significantly from December 2016 in pairwise comparisons and had about 37\% lower $\mathrm{N}$ (Figure 6a). For saturated soils, dormant season soil collections differed significantly by month $(P=0.01)$; specifically, samples collected in February, March and April 2017 were about 30\% lower than samples collected in January 2017 (Figure 6b). Soil samples collected in July 2017 had about two to three times more soil $\mathrm{N}$ content than samples collected during the winter season and exhibited greater spatial variability (Figure 6a). Soil samples collected in October 2017 were similar in N content to samples collected during the previous winter period (Figure 6a). 


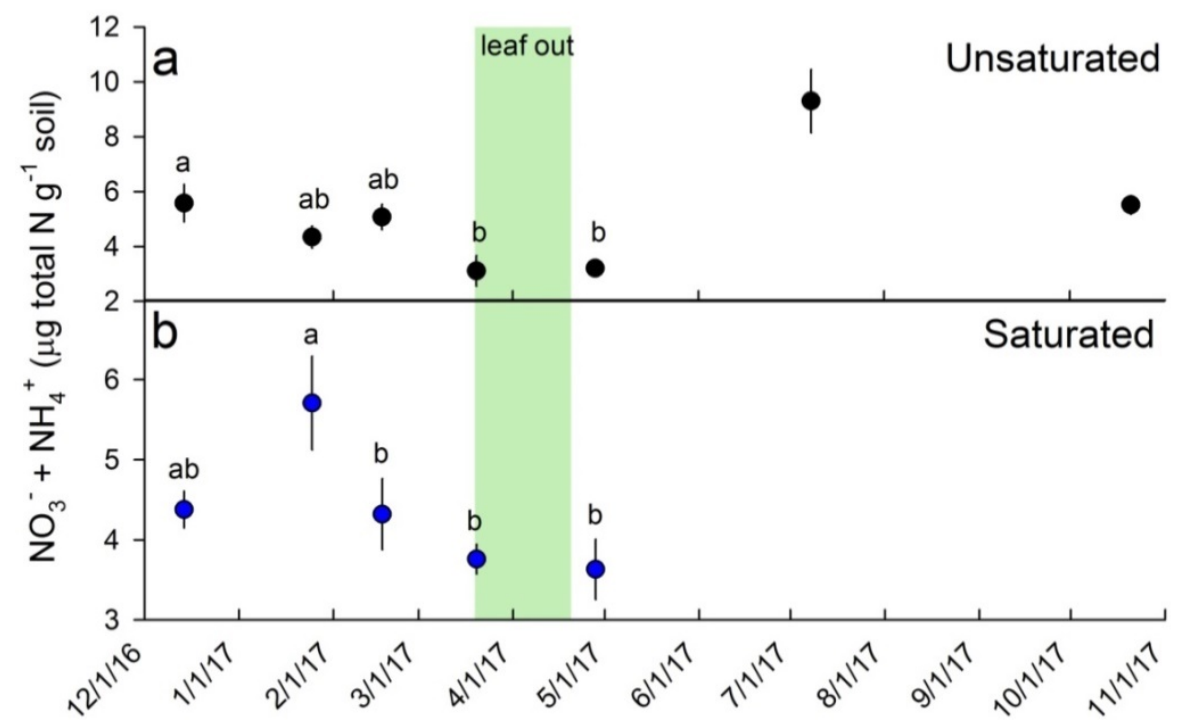

Figure 6. Monthly dormant season total nitrate- $\mathrm{NO}_{3}{ }^{-}$and ammonium- $-\mathrm{NH}_{4}{ }^{+}$( $\mu$ g total $\mathrm{N} \mathrm{g}^{-1}$ soil) in (a) unsaturated (black circles) and (b) saturated (blue circles) soil samples. Different letters in each soil category across dormant season months denote significant differences at $P<0.05$. The green box denotes when budbreak and leaf out of overstory trees occurred at the site.

\section{Discussion}

\subsection{Comparison of Parameters within and across Species}

In general, species within genera (for oaks and elms) were similar in terms of physiological parameters, but genera tended to differ significantly. In terms of the principal component analysis, oaks and elms were found across PC1, which captured variability in physiology, but oaks tended to be found in the negative region of PC2 (which captured variability in leaf anatomy) while elms were located in the positive region of PC2. However, green ash and shagbark hickory were both found under positive values of PC1. In particular, green ash had significantly higher leaf-level photosynthetic capacity and water use compared with oaks and elms, with shagbark hickory being intermediate. Therefore, green ash may require sites with more water availability, while oaks and elms can tolerate sites with less available water. In contrast, leaf anatomical and nutrient parameters differed significantly across species within the oak and elm genera, which is likely due to the decreased variation in the data compared with physiological parameters. For leaf $\mathrm{N}$ concentrations, willow oaks exhibited the lowest concentrations, while green ash and shagbark hickory exhibited some of the highest leaf $\mathrm{N}$ concentrations across species, suggesting greater nutrient uptake capacity and potential uses for nitrogen mitigation purposes. Across all measured species, LMA was statistically similar both within and across genera, which is likely due to the large within-species variability between leaves for this parameter. These results differ from expectations and from the results of other studies which found that LMA displayed wide-ranging variability across species within a given site [8,27]. In addition, principal component analysis showed that LMA grouped with leaf physiological and nutrient parameters as opposed to leaf area and leaf anatomical parameters. Overall, these data suggest that green ash and shagbark hickory are physiologically similar in terms of leaf functioning, while elms and oak exhibit broad variability in physiological functioning. Likewise, these results show that differing leaf anatomical properties can yield similar physiological functioning, particularly with regard to the oak genera.

Although it is often a representation of spatial and temporally integrated water use efficiency [28], $\delta^{13} \mathrm{C}$ was not significantly correlated with either instantaneous WUE or iWUE. Populus varieties under well-watered conditions also showed no correlation between $\delta^{13} \mathrm{C}$ and WUE [29]. Indeed, in terms of principal component analysis, $\delta^{13} \mathrm{C}$ loaded more strongly with PC2 which included mainly 
leaf anatomic parameters as opposed to PC1 which included the water use efficiency parameters. In addition, interpretations of differences in water use efficiency across genera vary depending on whether instantaneous gas exchange parameters (WUE or iWUE) or $\delta^{13} \mathrm{C}$ values were compared. For water use efficiency derived from gas exchange, genera were similar except for green ash, which displayed a significantly lower iWUE. However, for carbon isotopes, elms differed significantly from oaks, which exhibited more negative $\delta^{13} \mathrm{C}$ values. Asner et al. [9] found that both the intra- and interspecific variation in $\delta^{13} \mathrm{C}$ in species-diverse tropical forests was significantly lower than other leaf parameters, suggesting that it may not be a useful surrogate for leaf functional diversity. Since all leaves were collected from similar canopy heights using a pole pruner, they likely received atmospheric $\mathrm{CO}_{2}$ with similar isotopic concentrations. Overall, interpretations of water use efficiency from $\delta^{13} \mathrm{C}$ values vs. leaf gas exchange across species may differ due to species differences in mesophyll conductance [30] and the location and timing of carbon assimilation used for leaf structural components [31,32].

In general, the variability in terms of diversity quotients (Table 3) across species in this bottomland hardwood forest was greater for water use parameters than photosynthetic carbon uptake and leaf nitrogen parameters. This suggests that, across species, there is a larger diversity of water use strategies as compared with nitrogen use strategies in this bottomland hardwood forest. This could also mean that this ecosystem contains a greater diversity of niches for water use compared with nitrogen availability, although Marks and Lechowicz [33] found that different functional characteristics can achieve similar fitness under the same environmental conditions. Santiago and Wright [27] also observed a larger variation in stomatal conductance than leaf nutrient parameters. However, overall, they saw larger variability across species than this study, although they compared leaves across all growth forms (understory herbs, trees, lianas) in a tropical forest. Leaf anatomical parameters displayed the widest differences across species, therefore diversity of leaf anatomy in terms of water transport may explain some of the diversity in leaf-level water use across species as well.

\subsection{Correlations across Parameters}

As opposed to other studies that found a positive correlation between LMA and $\mathrm{V}_{C \max }$ or photosynthetic assimilation rates $[27,34,35]$, for these bottomland hardwood tree species we found that leaves with a higher LMA had lower $\mathrm{V}_{\mathrm{Cmax}}$ and net photosynthetic rates (Figure 1a). This suggests that a higher LMA limits $\mathrm{V}_{\mathrm{Cmax}}$, potentially through a decrease in $\mathrm{CO}_{2}$ diffusion to Rubisco sites (i.e., decreased mesophyll conductance) compared with leaves with a lower LMA. Indeed, LMA grouped with water use efficiency parameters in terms of principal component analysis, suggesting that a higher LMA could limit the diffusion of both $\mathrm{CO}_{2}$ and water vapor between leaf air spaces and the atmosphere. $\mathrm{V}_{\mathrm{Cmax}}$ was also negatively correlated with vein density (Figure $1 \mathrm{~b}$ ), which is contrary to expectations based on studies showing an increase in leaf hydraulic conductance with increasing vein density [36]. However, a negative relationship could suggest that increased vein density decreases the proportion of mesophyll cells performing photosynthetic reactions. $\mathrm{V}_{\mathrm{Cmax}}$ was also negatively correlated with stomatal density (Figure 1c), which appears contradictory as more stomata should allow for higher $\mathrm{CO}_{2}$ concentrations inside leaves. We also found that stomatal density was negatively correlated with whole-tree water use (Figure 2a) and leaf-level stomatal conductance $\left(P=0.006 ; r^{2}=0.26\right)$, suggesting that greater stomatal densities do not yield a greater conductance for $\mathrm{CO}_{2}$ and water vapor through the epidermis in these species. $V_{C \max }$ was also correlated with nitrogen parameters; leaves with lower $\mathrm{C} / \mathrm{N}$ ratios and a higher $\delta^{15} \mathrm{~N}$ exhibited a greater $\mathrm{V}_{\mathrm{Cmax}}$ (Figure 1d,e). Data are scarce comparing leaf $\delta^{15} \mathrm{~N}$ with physiological data; however, this parameter has been used to identify the source of leaf $\mathrm{N}$. Although many soil factors affect $\delta^{15} \mathrm{~N}$, in general, greater $\mathrm{N}$ cycling and $\mathrm{N}$ availability are associated with larger foliar $\delta^{15} \mathrm{~N}$ [37-39]. Therefore, greater foliar $\delta^{15} \mathrm{~N}$ may signify greater tree access to $\mathrm{N}$ and provide a more accurate estimate of functional leaf $\mathrm{N}$ content than estimates of leaf $\mathrm{N}$ concentration alone.

We also found a negative correlation between PNUE and iWUE (Figure 3b), suggesting a tradeoff between using water and using nitrogen efficiently in this system. Other studies have reported a 
similar tradeoff between water and nitrogen use efficiency in resource-limited environments [40-44], in that stomatal closure limits $\mathrm{CO}_{2}$ intake and photosynthetic rates per unit leaf nitrogen. Concurrently, leaves that efficiently utilize leaf $\mathrm{N}$ require more $\mathrm{CO}_{2}$ uptake and more open stomata, decreasing water use efficiency. Unlike the negative correlation between iWUE and PNUE, there was a positive relationship between PNUE and $\delta^{13} \mathrm{C}$ (Figure 3c), with trees exhibiting less negative $\delta^{13} \mathrm{C}$ exhibiting the highest PNUE. Traditionally, less negative $\delta^{13} \mathrm{C}$ values have been associated with higher WUE in leaves; however, this result suggests that less negative $\delta^{13} \mathrm{C}$ may be due to greater photosynthetic assimilation per unit leaf $\mathrm{N}$ and higher incorporation of ${ }^{13} \mathrm{C}$ into leaf tissue as opposed to stomatal limitation on internal $\mathrm{CO}_{2}$ concentrations [28]. Interestingly, there was a negative correlation between LMA and PNUE across species, with leaves with a lower LMA exhibiting higher PNUE than leaves with higher LMA (Figure 3a). Scartazza et al. [34] also found a similar negative relationship between LMA and PNUE in European beech (Fagus sylvatica L.) across leaves throughout the canopy profile. A negative relationship between LMA and PNUE could suggest that the increased mesophyll resistance that accompanies leaves with greater LMA affects photosynthetic rates more negatively than potential increases in photosynthesis from increased leaf thickness [45].

On a tree-level basis, we found that species with a higher canopy-level stomatal density had lower whole-tree seasonal water use (scaled per unit leaf area) and were less responsive to the environmental parameters of PPFD and VPD (Figure 2). We also found positive correlations between stomatal density and overall tree height and DBH with larger, taller trees having leaves with greater stomatal density than shorter trees (Figure S1). Therefore, these taller trees with higher stomatal densities may exhibit less water use per unit leaf area due to hydraulic limitations with increasing height $[46,47]$, leading to a negative correlation between water use and stomatal density. In addition, Drake et al. [48] suggested that higher stomatal densities allow for greater control over aperture and faster stomatal response, which would benefit species sensitive to changes in environmental drivers such as PPFD, VPD and soil moisture and lead to overall lower water use during times of drought stress. However, we also found that trees with a lower stomatal density were more responsive on a daily timescale to changes in PPFD and VPD than trees with more stomata. Because responsiveness in this case was estimated from the slopes of the relationships between daily water use and environmental parameters, it is likely that trees with greater water use would exhibit a greater range of water use conditions and therefore exhibit a higher slope term. On a leaf-level basis, species with greater stomatal density had greater water use efficiencies and lower stomatal conductance. This result is consistent with findings of other studies [49-51] reporting that stomatal density was positively correlated with water use efficiency.

\subsection{Intra-Species Variability in Stomatal Properties}

Regarding stomatal length, plasticity quotients were under two for all measured species. These results differ from those of Sack et al. [52], who found that stomatal and/or guard cell length did not vary across the crowns of open grown, temperate deciduous trees within a given species. In terms of stomatal density, plasticity quotients in this study were larger than for stomatal length (ranging from 1.5 to 2.7); however, species rankings remained similar. Sack et al. [52] report lower plasticities in stomatal density for open-grown deciduous trees ranging from 1.1 to 1.5. In addition, they reported that plasticity quotients for all variables were less than 2 across tested parameters. The similar lower plasticities across species may result from the open-grown individuals measured by Sack et al. [52], whereas this study measured individuals throughout a closed-canopy forest. However, Le Roux et al. [53] found canopy plasticity quotients for LMA and $\mathrm{N}_{\text {area }}$ of 2.8 and 3, respectively, for open-grown walnut trees. Therefore, the degree of canopy plasticity may differ both across species and depending on the variable in question.

The variability in stomatal parameters across leaves collected throughout the crowns of individual species may also provide insights into the variability in potential physiological parameters. Across all study species, stomatal density was significantly correlated with $\mathrm{V}_{\mathrm{Cmax}}$, net photosynthetic rates and water use efficiency. Likewise, stomatal densities between gas exchange and whole crown leaves were 
statistically similar in swamp chestnut oak, shagbark hickory and American elm (Figure 5a). Therefore, for these species, measured $V_{C \max }$ and other physiological parameters may be more representative of whole crown metrics than for other species. For species which differed significantly in terms of their stomatal density, relationships between gas exchange leaves and whole crown leaves may be useful in determining the range of variability in physiological parameters throughout crown locations based on anatomic variability. Due to difficulties in gaining canopy access at this site, lower branches were cut to measure gas exchange and physiological parameters. Leaves from these low branches differed significantly in terms of their stomatal densities for cherrybark and willow oak and were marginally different for water oak and winged elm (Figure 5a) suggesting they are more representative of shade leaves in terms of their anatomy, and likely also their physiology. Koike et al. [54] found that early successional species exhibited greater differences in photosynthetic rates between sun and shade leaves compared with mid and late-successional species. Our findings are similar, in that data from early successional oaks are more representative of shade leaves while data from mid-successional shagbark hickory and American elm may be more representative of a broader range of canopy leaves.

\subsection{Denitrification and N Limitations}

In terms of soil $\mathrm{N}$ concentrations during the winter saturation period, we observed declining inorganic soil $\mathrm{N}$ from January to the period of tree leaf out, particularly for saturated soils (Figure 6). However, the December inorganic N measurement for saturated soils did not differ significantly from measurements made in February to April; therefore, it is unclear whether soil $\mathrm{N}$ availability significantly declined over the saturation period. It is clear, however, that inorganic soil $\mathrm{N}$ is at low levels during leaf out and is about one-third of the amount measured during the summer growing season. Indeed, diversity quotients across species for leaf $\mathrm{N}$ concentration were low in this system, suggesting that each measured species is equally limited in terms of $\mathrm{N}$ acquisition. Due to the seasonal variation in decomposition rates, the results suggest a majority of nitrogen mineralization and nitrification occurred during the growing season months when temperatures were higher and microbes were active [55], resulting in an increased soil nitrogen content in July [56,57]. In a temperate broadleaf forest with hot humid summers, Yan et al. [58] observed temporal trends in nitrogen mineralization and found mineralization rates peak in the early summer before reaching the lowest values in mid-summer to fall. Total inorganic nitrogen concentrations in July were similar to those observed in an old growth hardwood forest in Germany as well as values observed in a central Appalachian hardwood forest $[59,60]$. During the saturation period of low soil oxygen, denitrification can result in $\mathrm{N}$ loss. Bottomland hardwood sites without direct connections to surface water tend to exhibit lower denitrification potential than sites that are surface water-influenced, but denitrification potentials of $0.167 \mu \mathrm{g}$ of $\mathrm{N}_{2} \mathrm{O}-\mathrm{N}$ evolved $\mathrm{g}^{-1}$ soil $\mathrm{hr}^{-1}$ have been exhibited [5]. In addition, throughout the growing season, nitrate can be lost from the system through leaching. Both denitrification and nitrate leaching should result in the enrichment of ${ }^{15} \mathrm{~N}$ in the soil $\mathrm{N}$ pool and potentially in foliage $\mathrm{N}$ [37]. Our foliage $\delta^{15} \mathrm{~N}$ values were higher than those reported by Templer et al. [38], in which all tree species exhibited negative $\delta^{15} \mathrm{~N}$ in a northeastern US forest. However, more data are needed to confirm that our largely positive $\delta^{15} \mathrm{~N}$ values correspond to soil $\mathrm{N}$ losses.

\section{Conclusions}

Overall, these findings highlight the degree of functional redundancy for leaf-level gas exchange in this bottomland hardwood forest both within and across genera, with most species displaying statistically similar leaf-level physiological parameters with the exception of green ash in most cases. For elms and oaks, this statistical similarity is the result of the high variability within species, with individuals in these genera located throughout PC1 which represented leaf physiological functioning. In contrast, green ash and shagbark hickory exhibited less variability in leaf physiology, grouping together in PC1. In terms of the diversity across species, water use parameters and leaf anatomy related to water use displayed both greater variability among species and greater plasticity 
within species, suggesting a more variable environment in terms of water availability and water use strategies compared with nutrient availability and the light regime. In bottomland hardwood forests, fine scale changes in topography and hydrology can lead to differences in alluvial deposition, soil texture and soil water availability [2], likely creating variable niches for water use. Finally, these results can aid in modeling photosynthetic capacity and gas exchange parameters from leaf anatomical parameters; however, our key results differed from other studies. For example, LMA was negatively correlated with $\mathrm{V}_{\mathrm{Cmax}}$ and $\delta^{13} \mathrm{C}$ was uncorrelated with water use efficiencies estimated from gas exchange. These contradictory relationships highlight the potential importance of measuring more in-depth leaf parameters such as mesophyll conductance and diffusional limitations to gain a more complete picture of the interaction of leaf anatomical parameters and overall physiological functioning.

Supplementary Materials: The following are available online at http://www.mdpi.com/1999-4907/11/5/519/s1, Table S1: Sizes of trees measured for physiological parameters including diameter at breast height (DBH), height, height to live crown and mean crown width. Figure S1: Significant correlations between stomatal density $\left(\mathrm{mm}^{-2}\right)$ and (a) total tree height $(\mathrm{m})$ and $(\mathrm{b})$ tree diameter at breast height $(\mathrm{DBH} ; \mathrm{cm})$

Author Contributions: Conceptualization, Z.K. and H.J.R.; methodology, Z.K., J.N.Y. and H.J.R.; formal analysis, Z.K. and H.J.R.; investigation, Z.K., J.N.Y. and H.J.R.; writing-original draft preparation, Z.K. and H.J.R.; writing-review and editing, H.J.R.; All authors have read and agreed to the published version of the manuscript.

Funding: This research was funded by the National Institute of Food and Agriculture, U.S. Department of Agriculture, McIntire-Stennis project under accession number MISZ-399080

Acknowledgments: The authors thank N. Hornslein for fieldwork assistance. This publication is a contribution of the Forest and Wildlife Research Center, Mississippi State University.

Conflicts of Interest: The authors declare no conflict of interest.

\section{References}

1. Battaglia, L.; Minchin, P.; Pritchett, D. Sixteen years of old-field succession and reestablishment of a bottomland hardwood forest in the Lower Mississippi Alluvial Valley. Wetlands 2002, 22, 1-17. [CrossRef]

2. Hodges, J.D. Development and ecology of bottomland hardwood sites. Ecol. Manag. 1997, 90, 117-125. [CrossRef]

3. McKnight, J.S.; Hook, D.D.; Langdon, O.G.; Johnson, R.L. Flood tolerance and related characteristics of trees of the bottomland forests of the southern United States. In Wetlands of Bottomland Hardwood Forests; Clark, J.R., Benfordado, J., Eds.; Elsevier Scientific Publishing Co: New York, NY, USA, 1981; pp. $28-69$.

4. Hurst, N.; White, J.R.; Baustian, J. Nitrate reduction in a hydrologically restored bottomland hardwood forest in the Mississippi river watershed, northern Louisiana. Soil Sci. Soc. Am. J. 2016, 80, 1698-1705. [CrossRef]

5. Hunter, R.G.; Faulkner, S.P. Denitrification potentials in restored and natural bottomland hardwood wetlands. Soil Sci. Soc. Am. J. 2001, 65, 1865-1872. [CrossRef]

6. Gardiner, E.S.; Oliver, J.M. Restoration of bottomland hardwood forests in the Lower Mississippi Alluvial Valley, USA. In Restoration of Boreal and Temperate Forests; Stanturf, J.A., Madsen, P., Eds.; CRC Press: Boca Raton, FL, USA, 2005; pp. 235-251.

7. Rousseau, R.; Ezell, A.; Hodges, J.D. Bottomland Hardwood Management Species/Site Relationships; Mississippi State University: Mississippi State, MS, USA, 2004.

8. Asner, G.P.; Martin, R.E.; Ford, A.J.; Metcalfe, D.J.; Liddell, M.J. Leaf chemical and spectral diversity in Australian tropical forests. Ecol. Appl. 2009, 19, 236-253. [CrossRef] [PubMed]

9. Asner, G.P.; Martin, R.E.; Tupayachi, R.; Anderson, C.B.; Sinca, F.; Carranza-Jiménez, L.; Martinez, P. Amazonian functional diversity from forest canopy chemical assembly. Proc. Natl. Acad. Sci. USA 2014, 111, 5604-5609. [CrossRef]

10. Reich, P.B.; Ellsworth, D.S.; Walters, M.B.; Vose, J.M.; Gresham, C.; Volin, J.C.; Bowman, W.D. Generality of leaf trait relationships: A test across six biomes. Ecology 1999, 80, 1955-1969. [CrossRef]

11. Jucker, T.; Bouriaud, O.; Coomes, D.A. Crown plasticity enables trees to optimize canopy packing in mixed-species forests. Funct. Ecol. 2015, 29, 1078-1086. [CrossRef]

12. Cadotte, M.W.; Carscadden, K.; Mirotchnick, N. Beyond species: Functional diversity and the maintenance of ecological processes and services. J. Appl. Ecol. 2011, 48, 1079-1087. [CrossRef] 
13. Zhang, Y.; Chen, H.Y.H.; Reich, P.B. Forest productivity increases with evenness, species richness and trait variation: A global meta-analysis. J. Ecol. 2012, 100, 742-749. [CrossRef]

14. Schneider, F.D.; Morsdorf, F.; Schmid, B.; Petchey, O.L.; Hueni, A.; Schimel, D.S.; Schaepman, M.E. Mapping functional diversity from remotely sensed morphological and physiological forest traits. Nat. Commun. 2017, 8. [CrossRef] [PubMed]

15. Aranda, I.; Forner, A.; Cuesta, B.; Valladares, F. Species-specific water use by forest tree species: From the tree to the stand. Agric. Water Manag. 2012, 114, 67-77. [CrossRef]

16. Violle, C.; Reich, P.B.; Pacala, S.W.; Enquist, B.J.; Kattge, J. The emergence and promise of functional biogeography. Proc. Natl. Acad. Sci. USA 2014, 111, 13690-13696. [CrossRef] [PubMed]

17. Bögelein, R.; Thomas, F.M.; Kahmen, A. Leaf water ${ }^{18} \mathrm{O}$ and ${ }^{2} \mathrm{H}$ enrichment along vertical canopy profiles in a broadleaved and a conifer forest tree. Plant Cell Environ. 2017, 40, 1086-1103. [CrossRef] [PubMed]

18. Hetherington, A.; Woodward, F.I. The role of stomata in sensing and driving environmental change. Nature 2003, 424, 901-908. [CrossRef] [PubMed]

19. Keenan, T.F.; Niinemets, U. Global leaf trait estimates biased due to plasticity in the shade. Nat. Plants 2016, 3. [CrossRef]

20. Escribano-Rocafort, A.G.; Ventre-Lespiaucq, A.B.; Granado-Yela, C.; Rubio de Casas, R.; Delgado, J.A.; Escudero, A.; Balaguer, L. Intraindividual variation in light-related functional traits: Magnitude and structure of leaf trait variability across global scales in Olea europaea trees. Trees 2017, 31, 1505-1517. [CrossRef]

21. Natural Resources Conservation Service. United States Department of Agriculture. Web Soil Survey. Available online: https://websoilsurvey.sc.egov.usda.gov/App/HomePage.htm/ (accessed on 17 April 2018).

22. Arguez, A.; Durre, I.; Applequist, S.; Squires, M.; Vose, R.; Yin, X.; Bilotta, R. NOAA's U.S. Climate normals (1981-2010). NOAA Natl. Cent. Environ. Inf. 2010. [CrossRef]

23. Kassahun, Z. The Influence of Environmental Factors on the Physiological Function of Eight Co-Occurring Species on a Minor Bottomland Hardwood Stand; Mississippi State University: Mississippi State, MS, USA, 2018.

24. Sharkey, T.D.; Bernacchi, C.; Farquhar, G.D.; Singsaas, E. Fitting photosynthetic carbon dioxide response curves for $\mathrm{C}_{3}$ leaves. Plant Cell Environ. 2007, 30, 1035-1040. [CrossRef]

25. Maynard, D.G.; Kalra, Y.P. Nitrate and exchangeable ammonium nitrogen. In Soil Sampling and Methods of Analysis; Carter, M.R., Ed.; Lewis Publishers: Boca Raton, FL, USA, 1993; pp. 25-38.

26. R Core Team. R: A Language and Environment for Statistical Computing; R Foundation for Statistical Computing: Vienna, Austria, 2014.

27. Santiago, L.S.; Wright, S.J. Leaf functional traits of tropical forest plants in relation to growth form. Funct. Ecol. 2007, 21, 19-27. [CrossRef]

28. Farquhar, G.D.; Ehleringer, J.R.; Hubick, K.T. Carbon isotope discrimination and photosynthesis. Annu. Rev. Plant Physiol. Plant Mol. Biol. 1989, 40, 503-537. [CrossRef]

29. Monclus, R.; Dreyer, E.; Villar, M.; Delmotte, F.; Delay, D.; Petit, J.; Barbaroux, C.; Le Thiec, D.; Bréchet, C.; Brignolas, F. Impact of drought on productivity and water use efficiency in 29 genotypes of Populus deltoides $\times$ Populus nigra. New Phytol. 2006, 169, 765-777. [CrossRef] [PubMed]

30. Warren, C.R.; Adams, M.A. Internal conductance does not scale with photosynthetic capacity: Implications for carbon isotope discrimination and the economics of water and nitrogen use in photosynthesis. Plant Cell Environ. 2006, 29, 192-201. [CrossRef] [PubMed]

31. Ponton, S.; Dupouey, J.L.; Bréda, N.; Dreyer, E. Comparison of water-use efficiency of seedlings from two sympatric oak species: Genotype x environment limitation. Tree Physiol. 2002, 22, 413-422. [CrossRef]

32. Ripullone, F.; Lauteri, M.; Grassi, G.; Amato, M.; Borghetti, M. Variation in nitrogen supply changes water-use efficiency of Pseudotsuga menziesii and Populus $\times$ euroamericana; a comparison of three approaches to determine water-use efficiency. Tree Physiol. 2004, 24, 671-679. [CrossRef]

33. Marks, C.O.; Lechowicz, M.J. Alternative designs and the evolution of functional diversity. Am. Nat. 2006, 167, 55-66. [CrossRef]

34. Scartazza, A.; Di Baccio, D.; Bertolotto, P.; Gavrichkova, O.; Matteucci, G. Investigating the European beech (Fagus sylvatica L.) leaf characteristics along the vertical canopy profile: Leaf structure, photosynthetic capacity, light energy dissipation and photoprotection mechanisms. Tree Physiol. 2016, 36, 1060-1076. [CrossRef]

35. Ellsworth, D.S.; Reich, P.B. Canopy structure and vertical patterns of photosynthesis and related leaf traits in a deciduous forest. Oecologia 1993, 96, 169-178. [CrossRef] 
36. Carins Murphy, M.R.; Jordan, G.J.; Brodribb, T.J. Cell expansion not cell differentiation predominantly co-ordinates veins and stomata within and among herbs and woody angiosperms grown under sun and shade. Ann. Bot. 2016. [CrossRef]

37. Craine, J.M.; Elmore, A.J.; Aidar, M.P.M.; Bustamante, M.; Dawson, T.E.; Hobbie, E.A.; Kahmen, A.; Mack, M.C.; McLauchlan, K.K.; Michelsen, A.; et al. Global patterns of foliar nitrogen isotopes and their relationships with climate, mycorrhizal fungi, foliar nutrient concentrations, and nitrogen availability. New Phytol. 2009, 183, 980-992. [CrossRef]

38. Templer, P.H.; Arthur, M.A.; Lovett, G.M.; Weathers, K.C. Plant and soil natural abundance $\delta^{15} \mathrm{~N}$ : Indicators of relative rates of nitrogen cycling in temperate forest ecosystems. Oecologia 2007, 153, 399-406. [CrossRef] [PubMed]

39. Garten, C.T., Jr.; van Miegroet, H. Relationships between soil nitrogen dynamics and natural ${ }^{15} \mathrm{~N}$ abundance in plant foliage from great smoky mountains national park. Can. J. Res. 1994, 24, 1636-1645. [CrossRef]

40. Broeckx, L.; Fichot, R.; Verlinden, M.; Ceulemans, R. Seasonal variations in photosynthesis, intrinsic water-use efficiency and stable isotope composition of poplar leaves in a short-rotation plantation. Tree Physiol. 2014, 34, 701-715. [CrossRef] [PubMed]

41. Field, C.; Merino, J.; Mooney, H.A. Compromises between water-use efficiency and nitrogen-use efficiency in five species of California evergreens. Oecologia 1983, 60, 384-389. [CrossRef] [PubMed]

42. Renninger, H.J.; Carlo, N.J.; Clark, K.L.; Schäfer, K.V.R. Resource use and efficiency, and stomatal responses to environmental drivers of oak and pine species in an Atlantic coastal plain forest. Front. Plant Sci. 2015, 6, 297. [CrossRef]

43. Poorter, H.; Evans, J.R. Photosynthetic nitrogen-use efficiency of species that differ inherently in specific leaf area. Oecologia 1998, 116, 26-37. [CrossRef] [PubMed]

44. DeLucia, E.H.; Schlesinger, W.H. Photosynthetic rates and nutrient-use efficiency among evergreen and deciduous shrubs in Okefenokee Swamp. Int. J. Plant Sci. 1995, 156, 19-28. [CrossRef]

45. Takashima, T.; Hikosaka, K.; Hirose, T. Photosynthesis or persistence: Nitrogen allocation in leaves of evergreen and deciduous Quercus species. Plant Cell Environ. 2004, 27, 1047-1054. [CrossRef]

46. Yoder, B.J.; Ryan, M.G.; Waring, R.H.; Schoettle, A.W.; Kaufman, M.R. Evidence of reduced photosynthetic rates in old trees. Forest Sci. 1994, 40, 513-527.

47. Ryan, M.G.; Phillips, N.; Bond, B.J. The hydraulic limitation hypothesis revisited. Plant Cell Environ. 2006, 29, 367-381. [CrossRef]

48. Drake, P.L.; Froend, R.H.; Franks, P.J. Smaller, faster stomata: Scaling of stomatal size, rate of response, and stomatal conductance. J. Exp. Bot. 2013, 64, 495-505. [CrossRef] [PubMed]

49. Abrams, M.D.; Kubiske, M.E. Leaf structural characteristics of 31 hardwood and conifer tree species in central Wisconsin: Influence of light regime and shade-tolerance rank. Ecol. Manag. 1990, 31, 245-253. [CrossRef]

50. Quero, J.L.; Villar, R.; Marañón, T.; Zamora, R. Interactions of drought and shade effects on seedlings of four Quercus species: Physiological and structural leaf responses. New Phytol. 2006, 170, 819-834. [CrossRef] [PubMed]

51. Beerling, D.J.; Kelly, C.K. Stomatal density responses of temperate woodland plants over the past seven decades of $\mathrm{CO}_{2}$ increase: A comparison of Salisbury (1927) with contemporary data. Am. J. Bot. 1997, 84, 1572-1583. [CrossRef] [PubMed]

52. Sack, L.; Melcher, P.J.; Liu, W.H.; Middleton, E.; Pardee, T. How strong is intracanopy plasticity in temperate deciduous trees? Am. J. Bot. 2006, 93, 829-839. [CrossRef] [PubMed]

53. Le Roux, X.; Sinoquet, H.; Vandame, M. Spatial distribution of leaf dry weight per area and leaf nitrogen concentration in relation to local radiation regime within an isolated tree crown. Tree Physiol. 1999, 19, 181-188. [CrossRef]

54. Koike, T.; Kitao, M.; Maruyama, Y.; Mori, S.; Lei, T.T. Leaf morphology and photosynthetic adjustments among deciduous broad-leaved trees within the vertical canopy profile. Tree Physiol. 2001, 21, 951-958. [CrossRef]

55. Langhans, S.D.; Tockner, K. The role of timing, duration, and frequency of inundation in controlling leaf litter decomposition in a river-floodplain ecosystem (Tagliamento, northeastern Italy). Oecologia 2006, 147, 501-509. [CrossRef]

56. Dodla, S.K.; Wang, J.J.; DeLaune, R.D.; Cook, R.L. Denitrification potential and its relation to organic carbon quality in three coastal wetland soils. Sci. Total Environ. 2008, 407, 471-480. [CrossRef] 
57. Glazebrook, H.S.; Robertson, A.I. The effect of flooding and flood timing on leaf litter breakdown rates and nutrient dynamics in a river red gum (Eucalyptus camaldulensis) forest. Austral Ecol. 1999, 24, 625-635. [CrossRef]

58. Yan, E.R.; Wang, X.H.; Guo, M.; Zhong, Q.; Zhou, W.; Li, Y.F. Temporal patterns of net soil n mineralization and nitrification through secondary succession in the subtropical forests of eastern China. Plant Soil 2009, 320, 181-194. [CrossRef]

59. Gilliam, F.S.; Yurish, B.M.; Adams, M.B. Temporal and spatial variation of nitrogen transformations in nitrogen-saturated soils of a central Appalachian hardwood forest. Can. J. Res. 2001, 31, 1768-1785. [CrossRef]

60. Schrumpf, M.; Kaiser, K.; Schulze, E.D. Soil organic carbon and total nitrogen gains in an old growth deciduous forest in Germany. PLoS ONE 2014, 9, e89364. [CrossRef] [PubMed]

(C) 2020 by the authors. Licensee MDPI, Basel, Switzerland. This article is an open access article distributed under the terms and conditions of the Creative Commons Attribution (CC BY) license (http://creativecommons.org/licenses/by/4.0/). 